\title{
Nations and Nationalism: the first twenty-five years
}

\author{
John Hutchinson ${ }^{1}$ \\ Department of Government, London School of Economics
}

\begin{abstract}
[This paper reflects on salient aspects of the development of Nations and Nationalism over its first 25 years to become the leading journal in its field. It outlines the context of its founding, its interdisciplinary character, and the objectives to establish the subject of nationalism as a separate field of study. It discusses the strategies to advance the journal as a forum for scholarly exchange and how the journal has evolved. It outlines the rapid growth in the number of papers submitted to the journal and assesses the relation of the journal to the field today.

Key words: journal, field of nationalism, anniversary, interdisciplinarity]

Nations and Nationalism was launched in 1995 by the Association for the Study of Ethnicity and Nationalism (ASEN), which was founded between 1990 and 1991 by postgraduate students at the London School of Economics and Political Science under the leadership of Professor Anthony Smith with the wholehearted support of Professors James Mayall (who first suggested the idea of an association), Percy Cohen and George Schöpflin. Courses on nationalism had existed since 1980 at the LSE, but it was the collapse of the Soviet Union and, with it, the resurgence of nationalism in the former Eastern bloc, which triggered the growth in student numbers and in particular
\end{abstract}

\footnotetext{
${ }^{1}$ Athena Leoussi provided invaluable information about the founding of the journal and the early issues, as did Seeta Persaud about its management. Thanks to Gordana Uzelac for the tables and charts.
} 
postgraduate interest in nationalism that provided the stimulus for first ASEN and then the journal.

The idea of an academic, fully refereed journal that would publish scholarly research on the now thriving field of nationalism studies, a field that had already been growing since the 1960s with the rise of ethno-regionalism, was part of the expansion of ASEN's activities. It would further extend the initial idea to create a network of scholars and to organise an annual conference, an annual public lecture and series of seminars and mini-conferences. It would also complement Daniele Conversi's ASEN Bulletin which had initiated the publication of short scholarly articles. The ASEN Bulletin would continue to flourish and develop into SEN (Studies in Ethnicity and Nationalism).

The foundations of the journal were firmly laid down during the academic year 1993-94. The journal was named after Ernest Gellner's by then classic book, Nations and Nationalism, of 1983. Anthony D. Smith, as President of ASEN, together with the two ASEN Chairs, Athena Leoussi and Obi Igwara, were mandated by the ASEN Executive Committee to explore the possibility of setting up the new journal and to set it up, should it prove feasible. The task was difficult. A publisher had to be found, an editorial committee and board had to be recruited and articles had to be supplied. An additional problem was that ASEN, the umbrella organisation, was primarily a student-powered organisation, even though these were doctoral research students. This raised problems, to some minds, of authority and reliability. But the case had many strengths: the international reputation of Anthony D. Smith as a doyen of nationalism studies; the respect that he commanded among scholars world-wide, a respect that quickly translated into long lists of fully committed members of the Editorial Committee and International Advisory Board of the journal; and the membership numbers of ASEN. Indeed, by 1994, when the negotiations with publishers reached their peak, ASEN counted 400 members. The members of ASEN would be the immediate readers of and subscribers to the journal - there was a ready market. 
It was Professor Jack E. Spence, whom Athena Leoussi had met at a friend's party, and who held Anthony D. Smith at high esteem, who mediated, with his usual enthusiasm for youthful scholarly enterprise, with Cambridge University Press (CUP) on behalf of ASEN. CUP would be the first publisher of Nations and Nationalism $(N \& N)$, with effect from January 1995. The case was also strengthened by the fact that the younger editorsto-be, Athena Leoussi and Obi Igwara had, by 1994, been appointed to academic positions, in Reading and Warwick, respectively. Igwara, Leoussi, Terry Mulhall and Anthony D. Smith, as Editor-in-Chief, served as the first editors of $N \& N$. In their work, they were substantially aided by the ASEN administration and the veterans of the first breakthrough conference, Daniele Conversi and Natividad Gutierrez who, although they would move on to senior academic positions abroad, would remain loyal supporters of ASEN as well as $N \& N$, as members of its International Advisory Board. Sadly, Obi Igwara died prematurely in 2002: her important contribution to the Journal and to ASEN is remembered by the Obi Igwara Lectures, focussed on African nationalism.

The problem of the actual contents of the journal, at least of its first few issues (there were 3 issues per volume, at first), until $N \& N$ would become more widely known, did not prove too difficult to solve. Material was supplied by a combination of sources: the papers from the ASEN conferences; specially commissioned articles, such as Edward Shils' 'Nation, nationality, nationalism and civil society', which appeared in the first issue and was one of his last writings; and calls for papers. Terry Mulhall would diligently commission book reviews and even write one himself to bump up the first issue. By 20 December 1995, Anthony Smith wrote a memo to his team of editors, Igwara, Leoussi and Kelvin Knight (who joined the editors for a short period), advising them how to deal with the 'immense backlog of articles in the pipeline'. The work was relentless; but N\&N had arrived.

Although over time the editorial team has been dominated by academics, the links with the student-led organisation have remained close. Nations and Nationalism reports to ASEN committees, student chairs of ASEN have sat on its editorial team, and it has 
regularly published themed sections and individual articles based on presentations at the annual ASEN conferences. These have relied heavily on student initiatives and leadership.

At the time of its founding the journal had few direct competitors. There were numerous journals on ethnicity, including Ethnic and Racial Studies, on whose editorial team Anthony Smith had sat. But there was only the semi-annual (and sometimes annual) Canadian Review of Studies in Nationalism (which expired in 2005) and Nationalities Papers, which was largely focused on the territories of the (former) Soviet Union and its neighbours. This was to change. In the same year Nationalism and Ethnic Politics appeared, followed by National Identities (1999) and Ethnopolitics (2005) but these had a more specialist focus. The editorial of the first issue of Nations and Nationalism in March 1995 set out the goals

(1) to be the vehicle of new research, both theoretical and empirical, and act as a forum for the exchange of views in the field;

(2) to identify and develop a separate subject-area as a field of study in its own right, and unify the body of scholars in the field; and

(3) to bring to the attention of the wider scholarly community, and the public, the need to treat the subject-area as a well-defined field of interdisciplinary study, which requires the collaboration of scholars from a variety of intellectual backgrounds.

The first issue contained articles from Anthony Smith, Michael Hechter, Bhikhu Parekh, George Schöpflin, Raymond Pearson and Edward Shils, and the articles of first volume reflected the contentions of the time. As well as addressing the theoretical debates still raging on the historical embeddedness vs the construction of nations (Smith, Parekh, Jan Penrose and Steven Grosby), they discussed the implications of the Soviet collapse (Pearson, Schöpflin, Anita Inder Singh), race and multiculturalism (George Mosse, John Rex, Pierre Van den Berghe), secession, conflict and international security (Michael Howard, Benyamin Neuberger) and nationalism and violence (Hechter). Contemporary 
concerns and agendas (social and political), changing over time, from gender, human rights, migration, and populism have always been represented in the pages of the journal.

It is fair to say that in fulfilling its objectives, the journal can be counted a success. Initially, publishing three issues per year containing articles and book reviews, the journal quickly expanded to four and has undergone considerable increase in numbers and range of articles and in diversification of format. From 1997 to 2018 new article submissions has more than tripled from 54 to (a projected) 180 for 2018, with an eighty per cent increase in article submissions since 2012, in spite of competition from new journals (see Table 1). This reflects the dynamism of the field and also the strong support of our publishers.

In 2000 the publication of the journal was transferred from Cambridge University Press to Blackwell, following negotiations between Anthony Smith and Sarah Phibbs of Blackwell. Blackwell (later becoming Wiley) assumed joint ownership (with ASEN) of the journal in 2006. Sarah Phibbs and the later Wiley teams have given strong support to $N \& N$. Like Cambridge before them, they have funded the annual Gellner lecture, and in 2002 the ASEN/Nations and Nationalism prize was established (later renamed the Dominique Jacquin-Berdal prize after the sudden death in 2006 of a young member of the editorial team of great promise). The aim of this prize is to encourage the next generation of scholars and is awarded for the best article by currently enrolled post-graduate students and those who have submitted their thesis within five years of the submission deadline. Wiley too have financed an Anthony D. Smith Book prize and a number of important commemorative events. Under Wiley the journal is published both in printed and electronic form and it moved to ScholarOne Manuscripts in 2016. The shift to online submissions has allowed for a considerable expansion in the number of articles submitted and consequently published per volume. To ease the backlogs, Wiley-Blackwell implemented in 2017 'Early View', which allows forthcoming articles to be viewed online and cited before appearing in print. The Journal has been on the Social Science Citation Index (ISI) for several years, which means that its impact factor can now be gauged, encouraging more submissions, especially from North America. The journal 
received the first Impact Factor (IF) in 2010. The journal is unusual in being ranked across multiple categories (Ethnic Studies, Political Science, Sociology and History) no doubt reflecting its diverse content and the diversity within the subject of Nationalism Studies. Recently the journal IF has increased to 0.679. A point of frustration is our inability to persuade the gatekeepers of the Citation Indexes to expand the present Ethnic Studies category in the Index to a more inclusive Nationalism and Ethnic Studies category.

Table 1: Submissions of new Articles :1997-2018

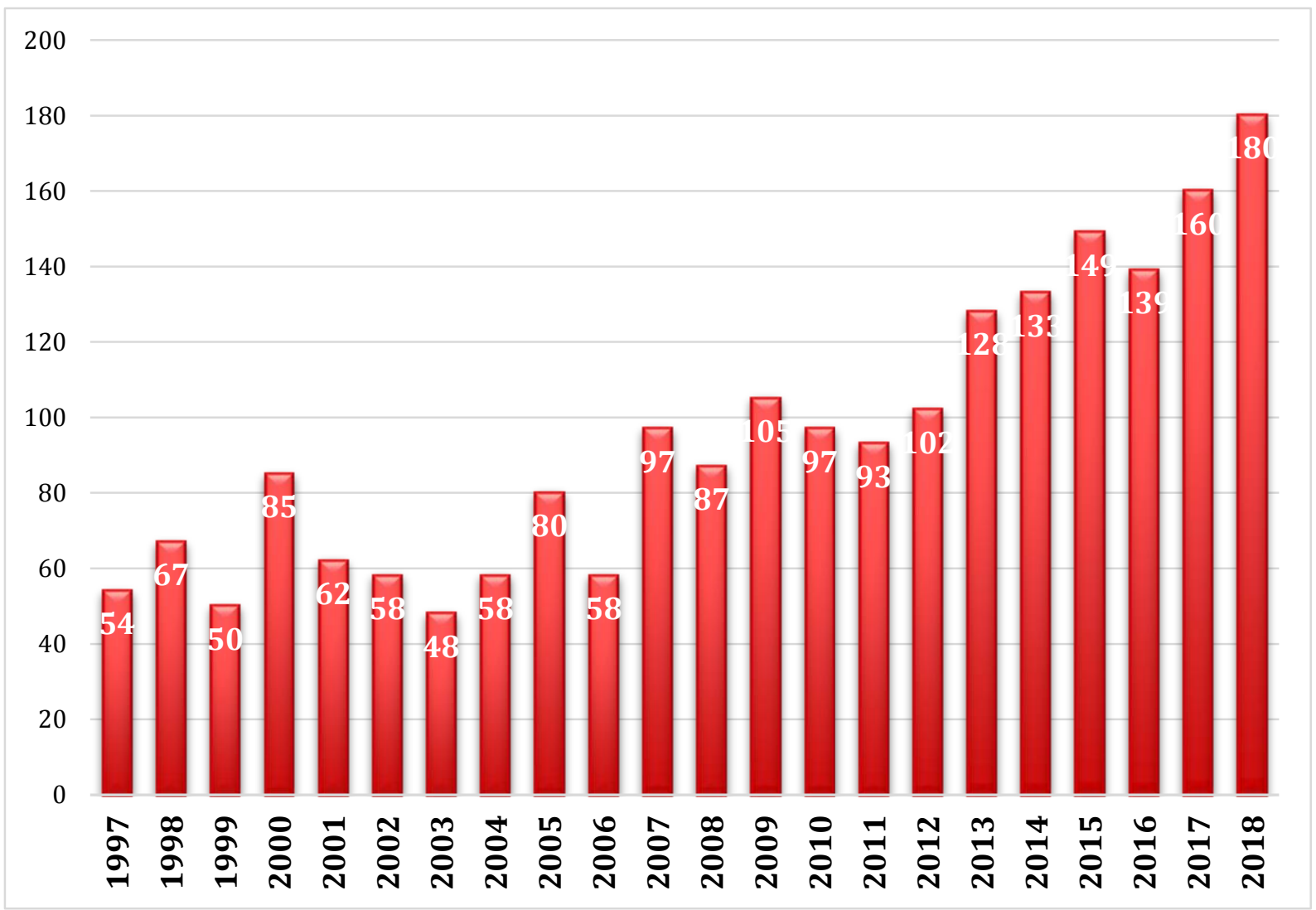

The early emphasis on interdisciplinarity came from an awareness that nationalism has permeated so many spheres of much of the modern world and that no single perspective can encompass it. It is instructive that many of the founding thinkers on nationalism entered the field having already achieved distinction in a wide range of disciplinary fields 
(for example, Elie Kedourie from the history of ideas, Ernest Gellner from social anthropology and philosophy, Eric Hobsbawm from economic and social history, Benedict Anderson from political anthropology, Adrian Hastings from religious history). We have, therefore, from the start appealed to scholars from across the social sciences and humanities. Anthony Smith's driving interest in theoretical innovation contributed to this distinctive feature of the journal, the high proportion $(27.1 \%)$ of general or theoretical submissions (Table 2).

This concern with theoretical advance has been sustained by certain institutional innovations, one of which was the establishment and publication of the annual Nations and Nationalism lecture that has been delivered by leading scholars on broad themes. Since 1995, this lecture commemorated Ernest Gellner, Anthony Smith's former teacher, but the Gellner lecture is now bi-ennial, alternating with the Anthony D. Smith Memorial Lecture which was inaugurated after the death of Anthony Smith in 2016. The Gellner lecture has been given by a 'Who's Who' of the leading scholars in Nationalism, in order: Michael Howard, Anthony D. Smith,_Roman Szporluk, Geoffrey Hosking, Fred Halliday, Brendan O'Leary, Dominique Schnapper, George Schöpflin, Sami Zubaida, Liah Greenfeld, Krishan Kumar, Thomas Hylland Eriksen, Craig Calhoun, Stein Tønnesson, John Darwin, John Breuilly, Randall Collins, Rogers Brubaker, David Martin, Joep Leerssen, John Hall and John Hutchinson. The inaugural Anthony D. Smith Lecture was given by Sammy Smooha, and the second lecture, in 2018, by Pål Kolst $\varnothing$.

This is but one of several formats developed to promote broad-ranging thinking about aspects of nationalism. In 2006 the journal introduced 'Viewpoint' articles to allow perspectives of a more general scope to readers (though this format has not been much used). There have been Symposia and Round Tables on the work of major scholars.

Among the most important of these formats is the publication of debates about recent books we believe advance new insights in the field. This was anticipated in 1996 by a symposium on David Miller's, On Nationality, but the first of these debates, held at the LSE was staged in 2005 (and published in 2006) on Michael Mann's The Dark Side of 
Democracy: Explaining Ethnic Cleansing. The selected books range from political theory, cultural history, historical and contemporary sociology and political science, and approaches and methodologies vary accordingly, from textual and documentary analysis, social surveys, quantitative studies and beyond. The books selected (in order) have been Krishan Kumar's The Making of English National Identity, John Hutchinson's Nations as Zones of Conflict; Aviel Roshwald's The Endurance of Nations, David Laitin's Nations, States and Violence, Henry Hale's The Foundations of Ethnic Politics: Separatism of States and Nations in Eurasia and the World, Joep Leerssen's, National Thought in Europe, Bernard Yack's, Nationalism and the Moral Psychology of Community, Azar Gat's Nations: The Long History and Deep Roots of Political Ethnicity and Nationalism, David McCrone's and Frank Bechhofer's Understanding National Identity, and Andreas Wimmer's Nation Building: Why Some Countries Come Together While Others Fall Apart.

Most of the foundational texts on nationalism emerged only in the 1980s and were authored by European and North American scholars, drawing in large part on the 'classic' European nationalisms for their models. A West European 'bias' is reflected in the content of the journal in which the largest group of articles (23.9\% Table 2) in 2016 examined Western European cases, as you will see from the accompanying tables. We have throughout sought contributions on neglected areas of the world and note a rising proportion of submissions on Asia and the Middle East. The total percentage of submissions on Asia up to 2006 was $10 \%$; now the submissions to 2016 is $16 \%$. The submissions up to 2016 for other areas were 11.3\% on Eastern Europe and 9.5\% on the Middle East, contrasting with $4.7 \%$ on Africa, $4.1 \%$ on North America, $2.3 \%$ on South America with Australia trailing at only $1.1 \%$. These biases are linked to the country of origins of our contributors. The introduction of Scholar One in 2016 gives us statistics of the country of origins of submitting authors: US 16.7\% , UK 15.5\%, Canada 9.5\%, Spain $6.5 \%$ Israel, $4.2 \%$, Denmark 3\%. It is hoped that the introduction of electronic submissions will encourage more articles from the developing world as the costs of transmitting articles reduces. 
Table 2 Submitted Articles to 2016 by area

\begin{tabular}{|l|c|c|}
\hline \multicolumn{1}{|c|}{ AREA } & Frequency & Percentage \\
\hline General & 523 & 27.1 \\
\hline Africa & 90 & 4.7 \\
\hline Western Europe & 461 & 23.9 \\
\hline Eastern Europe & 218 & 11.3 \\
\hline Middle East & 183 & 9.5 \\
\hline North America & 79 & 4.1 \\
\hline South America & 45 & 2.3 \\
\hline Australia & 20 & 1.1 \\
\hline Asia & 308 & 16.0 \\
\hline Total & 1927 & 100 \\
\hline
\end{tabular}

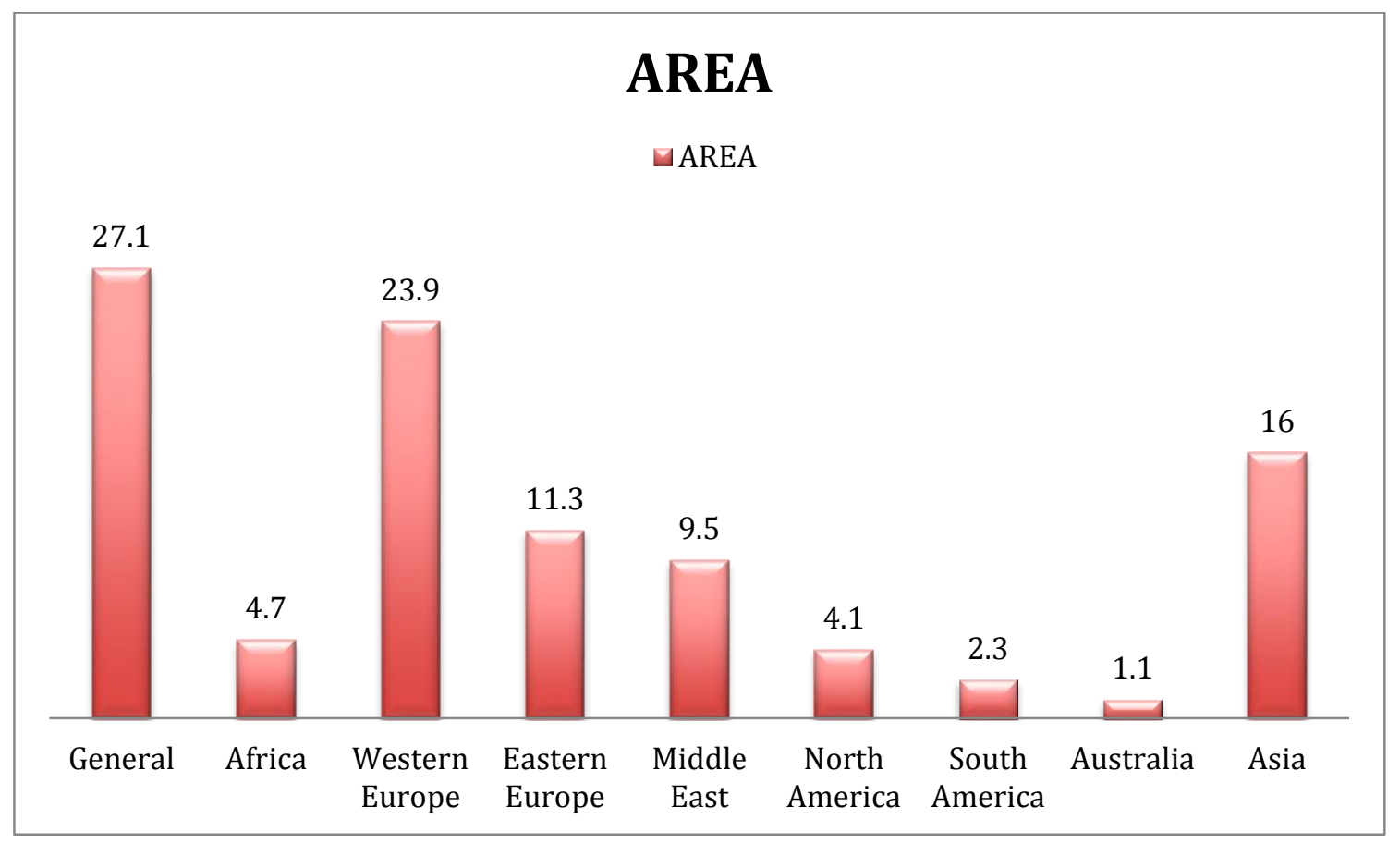


The journal has from its early days published Special Issues before replacing these with Themed Sections. We came to prefer Themed Sections because it was easier to manage their quality and they did not crowd out other articles. These have been occasionally commissioned or initiated by members of the editorial team, but normally result from approaches to the journal. The expectation is that articles making up these issues or sections must be more than the sum of their parts, seek to break new ground (theoretical and/or empirical) and have a coherence of approach. Occasionally too we have published Round Tables bringing together authors in discussion of a specific topic. These formats could also be a means of providing some redress to neglected geographies, approaches or topics in the field. We were pleased to have published such collections on such topics as 'Nationalism in Latin America' (2006), 'Jubilee independence commemorations in Africa' (2013), (contemporary) 'China nationalism and national identity' (2016). We have also addressed approaches/disciplines that are poorly represented, for example 'Nationalism and archaeology' (2001) and 'Classical music and nationalism' (2014) as well as new areas such as 'everyday nationalism' (2018). There remain areas that are sparsely represented which we would like to include. Geographical weak spots can be detected in the tables; disciplinary equivalents include anthropology, social psychology, and economic history. A full list of special issues and themed sections can be found here. ${ }^{i}$

Although the journal was founded by students who had just obtained their PhDs and performed as editors, Anthony Smith was key to its success. He closely guided the hand of the younger editors and, through his academic prestige, intellectual capacities, and his formidable political and negotiating skills, he was a vital force for both ASEN and its journal. Assuming the position of Editor-in- Chief in 1996 until 2015, he had to navigate the journal through an often difficult environment at the London School of Economics, which at times threatened its independence and survival. He did so in company with Seeta Persaud who joined the journal as Managing Editor in 1997. Seeta too has 
contributed greatly to the journal, as reference point between the editorial team and publishers, as contact person with referees, and through her administrative abilities, displayed not least in implementing the many new procedures arising from changes in the field of publishing. One of the results of their supportive work was the establishment of a team with a strong esprit de corps that was regularly replenished by younger scholars. The experienced academics who played leading roles up to 2001 were George Schöpflin, Josep Llobera, Montserrat Guibernau, Erica Benner and Brendan O’Duffy. Smith, however, also encouraged membership of the editorial team by $\mathrm{PhD}$ students (mostly with leadership roles within ASEN) viewing it as a useful academic training. There was a regular turnover of students, reflecting the demands of their postgraduate studies, with some serving as book review editors. The initial team comprised 6 (not including the Managing Editor), numbered 8 in 2002 but in 2017 had expanded to 18, largely because of the increased workload. This imposed a growing strain on Anthony Smith who from 2004 had suffered from leukaemia and led to John Hutchinson (who had joined in 2000) becoming deputy editor in 2006 and co-editor-in-chief in 2012. Anthony's illness forced his resignation as co-editor-in-chief in 2015. Following this, John Breuilly (who joined the journal in 2005) and Eric Kaufmann became co-editors-in-chief with John Hutchinson. There has been a regular turn-over of team members who have covered a wide range of disciplinary expertise and area specialisms. It would be invidious to select particular contributions from a conscientious and hard-working team, but we are grateful for the work of Gordana Uzelac for preparing the statistics for the annual report to the International Advisory Board. The current team comprises Benedikte Brincker, Jon Fox, Elliott Green, Montserrat Guibernau, , Daphne Halikiopoulou, Kristin Hissong, Atsuko Ichijo, Bill Kissane, Ellie Knott, Athena Leoussi, Ian Stewart, Rajesh Venugopal, Eric Woods.

The International Advisory Board (IAB) on which sit many of the luminaries of nationalism studies have played a key role in the success of the journal. The members of the International Advisory Board are often our first port of call when seeking referees or suggestions for names. Finding referees for a field which encompasses 
every continent (except Antartica) and ranges across the social sciences and humanities is a challenge. The increasing rate of submission has put pressures on our referees, who are essential for maintaining the quality of the journal. As Table 3 indicates, the rate of final acceptances has remained remarkably stable throughout the journal's history. It should be said that Wiley has recently introduced incentives for refereeing. We are, nonetheless, very grateful to all our large number of referees, often over-burdened academics, for vocational work which generally goes unrecognised, but without whom the academic and publishing world could not operate. The IAB has been an invaluable resource in many other respects in providing feedback on our progress and errors, making suggestions for future Gellner/Smith lectures, books for debate and so forth. It is invidious to single out particular members, but we should pay tribute to Michael Banton for his dedicated service over the entire history of the journal which persisted until his recent death at the age of 91, to Martin Bulmer (editor of our neighbouring journal, Ethnic and Racial Studies), to John Rex and to Jack Spence. Others who have been particular friends of the journal, many from its earliest days include Thomas Hylland Eriksen, Allon Gal, Susan-Mary Grant, Steven Grosby, Adrian Guelke, John Hall, Geoffrey Hosking, Paschalis Kitromilides, Jacob Landau, Stephanie Lawson, Joep Leerssen, Siniša Malešević, Benyamin Neuberger, Umut Ozkirimli, Jan Penrose, Sammy Smooha, John Stone, Stein Tønnesson, and Anna Triandafyllidou.

Table 3; Acceptance rate, 1997-2016 


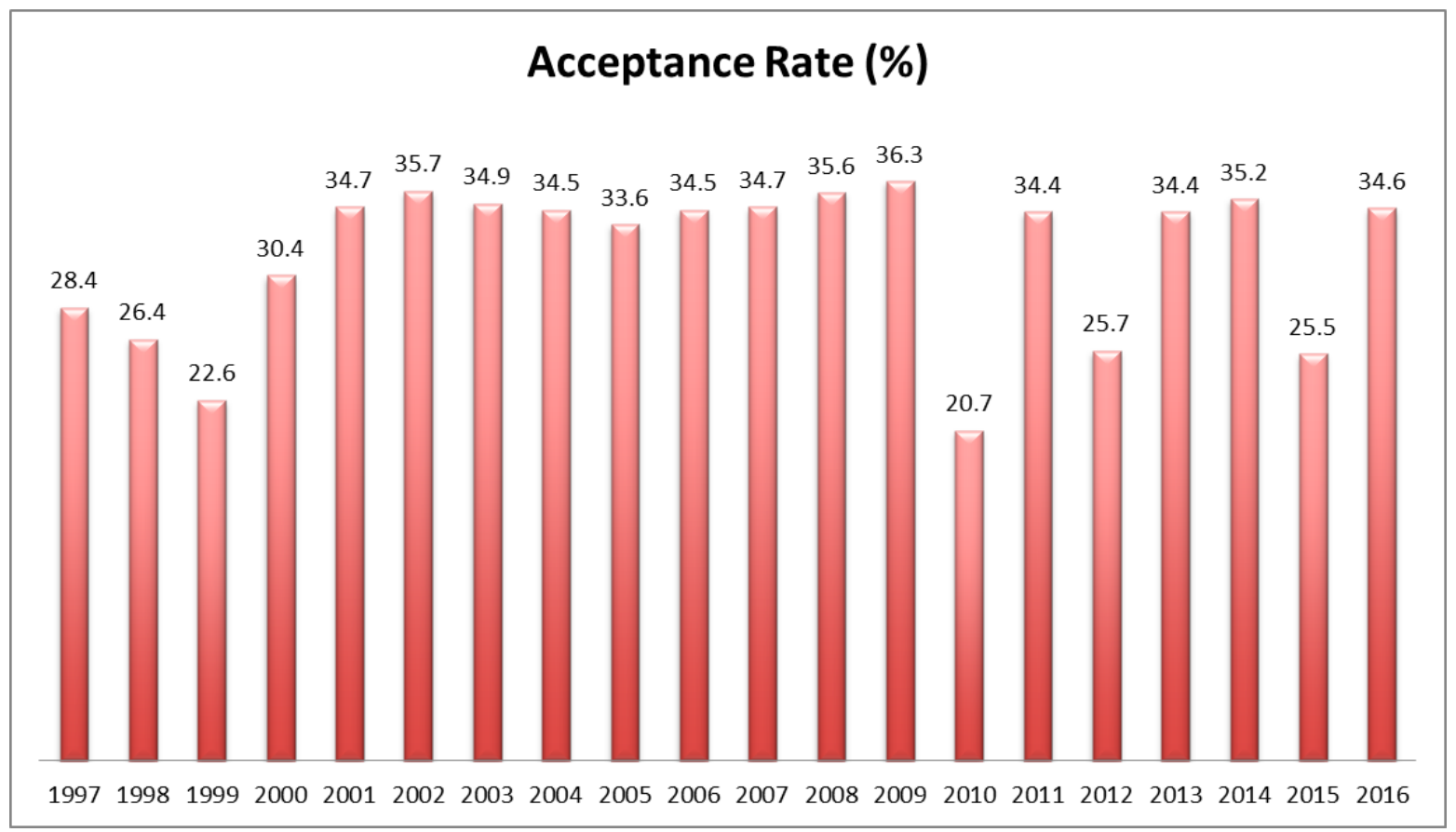

There have been a number of key moments in the journal's history which have resulted in notable publications. First there was the (re) publication in 1996 of the famous Warwick Debate in 1995 between Anthony Smith and Ernest Gellner over the navels of the nation and Smith's further thoughts. Second, there was the Special Issue, 'History and National Destiny: ethnosymbolism and its critics' (edited by Montserrat Guibernau and John Hutchinson and also published as a book) which marked the retirement in 2004 of Anthony Smith from the LSE. Third, Nations and Nationalism commemorated in 2010 its fifteenth anniversary with a well-attended special Anniversary Conference at LSE entitled 'National Identity in the Old and New Europe: Intellectuals, Culture and Popular Mobilisation'. The papers of the speakers, Athena Leoussi, Bernhard Giesen, Montserrat Guibernau, Joep Leersen, Siniša Malešević and Anthony Smith were published in 2011. Fourth, the twentieth anniversary was celebrated in 2015 by a Round Table on the theme of 'Why has nationalism not run its course?' and published in 2016. Introduced by Athena Leoussi, the speakers Geoffrey Hosking, Thomas Eriksen, Stein Tønnesson, and Erika Harris 
explored the present and future of nationalism world-wide. A fifth occasion was the major 2017 ASEN conference ‘Anthony Smith and the future of nationalism' following the death of Anthony Smith, the major papers of which were published in 2018. We plan to commemorate the twenty fifth anniversary by a Themed Section to be edited by John Breuilly focusing on the centenary of the formation of the League of Nations and what this has meant for nationalism and nation-state formation.

On a melancholy note, in recent years, following the death of so many of the founding figures of nationalism, the journal has published Symposia and Round Tables assessing their contribution to the field. The subjects included Adrian Hastings, John Armstrong, Benedict Anderson, Fredrik Barth, Anthony Smith, and Walker Connor.

The passing of these seminal figures of the 1980s and 1990s re-inforces the point that the field of nationalism is fast changing, and this is reflected in the journal. The major debates about the modernity of nations that created a field of exchange and generated so many of the central definitions, concepts and classifications have largely run their course. This has long been apparent, and the result is the differentiation into what might be called sub-fields - including gender, subaltern or postcolonial studies, ethnic conflict regulation, rational choice perspectives, and 'everyday' or 'banal' nationalism. From one perspective, this suggests a loss of intellectual coherence and a worrying loss of interest in general questions as academics follow the familiar paths of specialisation. Others might rejoin that this represents the 'maturity' of the field - that the major issues are much more settled enabling us to move on into new arenas which require different modes of analysis. New points of inquiry arise both from events in the real world (global mass migration, the resurgence of populism, the rise of political Islam, genocidal conflicts) and intellectual developments (for example, the rise of memory studies, discourse analysis and from the new approaches mentioned above). The content of the journal necessarily evolves in response to these changes, but with specialisation there is also a demand from within and outside the academy for publications like this journal by which to situate such phenomena within general frameworks. 
The journal thus aspires to serve the original objectives of the first editorial by remaining a common forum in which scholars can exchange ideas. But we cannot stand still and are aware we will have to do this in new ways. We have recruited student Social Media Officers to advise the team and help disseminate our scholarship. This year we publish our first 'Exchange' on topics of contemporary interest (in this case Populism). We have also initiated Virtual issues which are compendia of previous articles on a single theme. The increase in submissions of ideas for Themed sections often on contemporary issues and of individual articles is proof of the continuing need for Nations and Nationalism.

John Hutchinson

\author{
i 5(3) 1999 Chosen Peoples \\ 6(4) 2000 Gender and nationalism \\ 7(4) 2001 Nationalism and archaeology \\ 10 (1/2) 2004 History and national destiny: ethnosymbolism and its critics \\ 12(3) 2006 Varieties of Britishness \\ 14 (1) 2008 Partition/conflict Resolution \\ 14(4) 2008 Dominant groups \\ 14 (4) 2008 Ireland and Northern Ireland \\ 15(1) 2009 European Identity and Integration \\ 16 (1) 2010 National Identity and Constitutionalism in Europe \\ 16 (3) 2010 Englishness \\ 17(4) 2011Switzerland: a nation state or multinational state? \\ 17(2) 2011 National Identity in Old and New Europe \\ 19 (4) 2013 Nationalism and cultural sociology \\ 20 (2) 2014 Nationalist political rallies and cultural events \\ 21 (2) 2015 Nationalism in South East Asia \\ 21(4) 2015 Nationalism and revolution \\ 22 (4) 2016 China's periphery nationalism \\ 23 (2) 2017 Nationalism and belonging \\ 24 (1) 2018 State and historic buildings \\ 24 (2) 2018 Anthony Smith and the future of nationalism \\ 24(3) 2018 Everyday nationalism's evidence problem
}

